\title{
Biomass Enriched with Minerals via Biosorption Process as a Potential Ingredient of Horse Feed
}

\author{
Izabela Michalak ${ }^{1} \cdot$ Katarzyna Godlewska² $\cdot$ Krzysztof Marycz $^{3}$
}

Received: 13 October 2017 / Accepted: 22 May 2018 / Published online: 26 May 2018

(c) The Author(s) 2018

\begin{abstract}
In the present work, dry plant biomass that is commonly used in horses feeding: alfalfa, chopped grass pellets and chopped grass was used as a biosorbent of microelement ions: $\mathrm{Cr}(\mathrm{III}), \mathrm{Zn}(\mathrm{II}), \mathrm{Cu}(\mathrm{II})$ and $\mathrm{Mn}$ (II). Biosorption process was used to potentially enhance supplementation of minerals in horses diet. In order to characterize the biosorption properties of the examined biomass, preliminary experiments (kinetics and equilibrium studies) were conducted with $\mathrm{Cr}$ (III) ions. The effect of $\mathrm{pH}$ and initial metal ions concentration $\left(C_{0}\right)$ on the biosorption capacity $(q)$ was investigated. On this basis, the best experimental conditions were chosen ( $\mathrm{pH} 5, C_{\mathrm{S}} 1.0 \mathrm{~g} / \mathrm{L}$ (biomass content), $C_{0} 200 \mathrm{mg} / \mathrm{L}$ ). For them, biosorption of $\mathrm{Mn}(\mathrm{II})$, $\mathrm{Zn}(\mathrm{II}), \mathrm{Cu}(\mathrm{II})$ ions was carried out in a periodic and continuous system (biosorption column). Equilibrium of the biosorption was described using Langmuir equation. The mineral composition of the raw and enriched biomass was also examined using ICP-OES, as well as SEM-EDX technique. In general, the best biosorption properties were observed for alfalfa. The maximum biosorption capacity for $\mathrm{Zn}(\mathrm{II})$ was $27.5 \mathrm{mg} / \mathrm{g}$, for $\mathrm{Cu}(\mathrm{II})-38.5 \mathrm{mg} / \mathrm{g}$, for $\mathrm{Mn}$ (II) $-13.6 \mathrm{mg} / \mathrm{g}$ and for $\mathrm{Cr}$ (III) $-33.2 \mathrm{mg} / \mathrm{g}$. Therefore, the biomass of enriched alfalfa can be recommended as a feed supplement for horses.
\end{abstract}

Keywords Alfalfa $\cdot$ Chopped grass $\cdot$ Hay pellets $\cdot$ Biosorption $\cdot$ Microelements $\cdot$ Horse feed additive

\section{Statement of Novelty}

In the present work, we proposed for the first time to use biomass, commonly used in horse feeding as a carrier of microelements, especially with a diagnosed metabolic syndrome. Alfalfa, chopped grass pellets and chopped grass were used as biosorbents of microelement ions such as $\mathrm{Cr}$ (III), $\mathrm{Zn}$ (II), $\mathrm{Cu}$ (II) and $\mathrm{Mn}$ (II). Biosorption was used to enhance supplementation of minerals in horse diet.

Izabela Michalak

izabela.michalak@pwr.edu.pl

1 Department of Advanced Material Technologies, Faculty of Chemistry, Wrocław University of Science and Technology, Smoluchowskiego 25, 50-372 Wrocław, Poland

2 Department of Horticulture, The Faculty of Life Sciences and Technology, Wrocław University of Environmental and Life Sciences, pl. Grunwaldzki 24A, 50-363 Wrocław, Poland

3 Department of Experimental Biology, The Faculty of Biology and Animal Science, Wrocław University of Environmental and Life Sciences, Norwida 27b, 50-375 Wrocław, Poland

\section{Introduction}

Minerals play a crucial role in the horse diet although they constitute only a minor part of it. They are involved in many physiological processes and are integral parts of amino acids, hormones, vitamins [1]. In this paper we focused on copper, manganese, zinc and chromium which are required by horses in small quantities. Copper plays role in collagen stabilization, elastin syntheses, biomechanical properties of corneous processes of the skin and mobilization of iron stores and melanin syntheses [2]. Manganese is essential for carbohydrate and lipid metabolism, synthesis of chondroitin sulphate. It acts as a superoxide scavenger. Zinc is a component of metalloenzymes involved in protein and carbohydrate metabolism [1, 3]. Chromium is a component of glucose tolerance factor which potentates the action of insulin, as well as is involved in carbohydrate metabolism [4]. It's biological action is thought to elicit its effects by enhancing intracellular insulin receptor signalling pathways through enhancing tyrosine kinase activity or reduced tyrosine phosphatase activity [5]. This in consequence might potentially increase insulin sensitivity [5, 6]. Although chromium has been reported to have a beneficial effect in diabetes mellitus 
patients, contrary data exist in the field of equine nutrition $[5,7,8]$. Chameroy and colleagues have questioned the beneficial effect of chromium supplementation on morphometric measurements, blood variables, resting insulin concentrations or insulin sensitivity in laminitic obese horses [9]. However, other authors suggested, that chromium might improve insulin sensitivity by altering the intracellular signalling pathways initiated by the activated insulin receptor [5]. The contrary data might be also due to the source of chromium or its chemical form which especially in equine nutrition still require further investigation.

The main source of minerals for horses are forages and concentrates. Their content in feed and availability depend on soil mineral concentration, plant species, stage of maturity and conditions of harvesting [1]. According to the Nutrient Requirements of Horses [1], the content of microelements in a feedstuff differs - for example for copper it ranges from $1 \mathrm{mg} / \mathrm{kg}$ for corn to $80 \mathrm{mg} / \mathrm{kg}$ for cane molasses, for zinc it is from 15 to $40 \mathrm{mg} / \mathrm{kg}$, for manganese in forages from 40 to $140 \mathrm{mg} / \mathrm{kg}$ and most concentrates contain from 15 to $45 \mathrm{mg} / \mathrm{kg}$. According to the guidelines of Pagan et al. [4], the recommend dose of chromium in horse diet is $5.0 \mathrm{mg} /$ day. In order to prevent deficiencies of these elements, very often they are supplemented to the feed, mainly as inorganic salts-sulphates, chlorides, oxides, carbonates or less frequently organic-chelate. A crucial issue is the determination of oral bioavailability (which is usually low for inorganic salts) and appropriate dosages for mineral supplements used in horse feeding [9].

In this publication we propose to produce biological feed additives with microelements using biosorption process. This process may be defined as the binding of desired substances (e.g., metal ions) from aqueous solution by a biological material. Metal ions are bound with functional groups present on the surface of the cell wall [10]. The biosorption process can be performed using different types of low-cost biomass, that can be used in animal feeding [11, 12]. Here, we propose to apply traditionally used in equine feeding alfalfa, chopped grass pellets and chopped grass as a carrier of microelement ions- $\mathrm{Cu}(\mathrm{II}), \mathrm{Zn}$ (II), $\mathrm{Mn}$ (II) and $\mathrm{Cr}(\mathrm{III})$. In the literature the biomasses of alfalfa and grass are randomly studied as a biosorbent of metal ions. This biomass was rather treated as a biosorbent to remove metal ions such as $\mathrm{Er}(\mathrm{III}), \mathrm{Ho}(\mathrm{III}), \mathrm{Ni}(\mathrm{II}), \mathrm{Pb}(\mathrm{II}), \mathrm{Cr}(\mathrm{III})$ from wastewaters. Some of the examples are presented in Table 1.

In our previous studies we showed that biomass enriched with microelement ions constituted a source of highly bioavailable minerals to animals (laying hens, pigs, goats) and can partly replace traditionally used inorganic salts as a main source of microelements [20-22]. In these studies it was shown that the bioavailability of microelements from the enriched biomass was higher than from inorganic salts. The new feed additive produced from the biomass of alfalfa, chopped grass pellets and chopped grass additionally enriched with $\mathrm{Cu}(\mathrm{II}), \mathrm{Zn}(\mathrm{II}), \mathrm{Mn}$ (II) and $\mathrm{Cr}(\mathrm{III})$ can be used in horse feeding, especially with diagnosed equine metabolic syndrome (EMS) which is a serious endocrine disorder characterized by severe obesity, insulin resistance, systemic inflammation and past or chronic laminitis [23-25]. Most recently, herbal bioactive substances have been showed to possess a beneficial effect in EMS feeding through improvement of insulin sensitivity [26].

Dietary management in EMS horses involves feeding grass hay (restricted to $1.25 \%$ of body mass as daily dry matter intake) with the addition of vitamin and mineral supplements [27]. Hay with low non-structural carbohydrates (NSC; simple sugars, starch and fructan) content should be selected [25]. These non-structural carbohydrates can induce laminitis. They are digested rapidly and energy is released quickly for a short burst of energy [27, 28]. Additionally, soaking of hay is recommended because it results in a significant reduction in the content of these carbohydrates [27, 29]. Among mineral additives, especially chromium and magnesium are commonly recommended for the management of EMS [24, 25].

In the present paper we examined the biosorption properties of alfalfa, chopped grass pellets and chopped grass as a potential natural feed additives for horses with EMS. Preliminary experiments (kinetics and equilibrium studies) were conducted with $\mathrm{Cr}(\mathrm{III})$ ions in a batch system. The effect of $\mathrm{pH}$ and initial metal ions concentration $\left(C_{0}\right)$ on the biosorption capacity $(q)$ was investigated. On this basis, the best experimental conditions were chosen. For them, biosorption of $\mathrm{Mn}(\mathrm{II}), \mathrm{Zn}(\mathrm{II}), \mathrm{Cu}(\mathrm{II})$ ions was carried out in a batch, as well as in a fixed-bed column system. The potential of the enriched biomass as a feed additive for horses with EMS was discussed.

\section{Experimental}

\section{Materials}

\section{Chemicals}

All reagents: $\mathrm{Cr}\left(\mathrm{NO}_{3}\right)_{3} \cdot 9 \mathrm{H}_{2} \mathrm{O}, \mathrm{ZnSO}_{4} \cdot 7 \mathrm{H}_{2} \mathrm{O}, \mathrm{CuSO}_{4} \cdot 5 \mathrm{H}_{2} \mathrm{O}$, $\mathrm{MnSO}_{4} \cdot \mathrm{H}_{2} \mathrm{O}, \mathrm{NaOH}, \mathrm{HCl}$, EDTA were purchased from POCh S.A. Gliwice, Poland.

\section{Biosorbents}

Three following feed materials, commonly used in horse feeding were used as biosorbents for metal ions:

1. alfalfa (http://hippovetpl.shoper.pl/pl/p/Luzerne-Mix$20-\mathrm{kg} / 123)$ composed of young chopped alfalfa (50\%), 


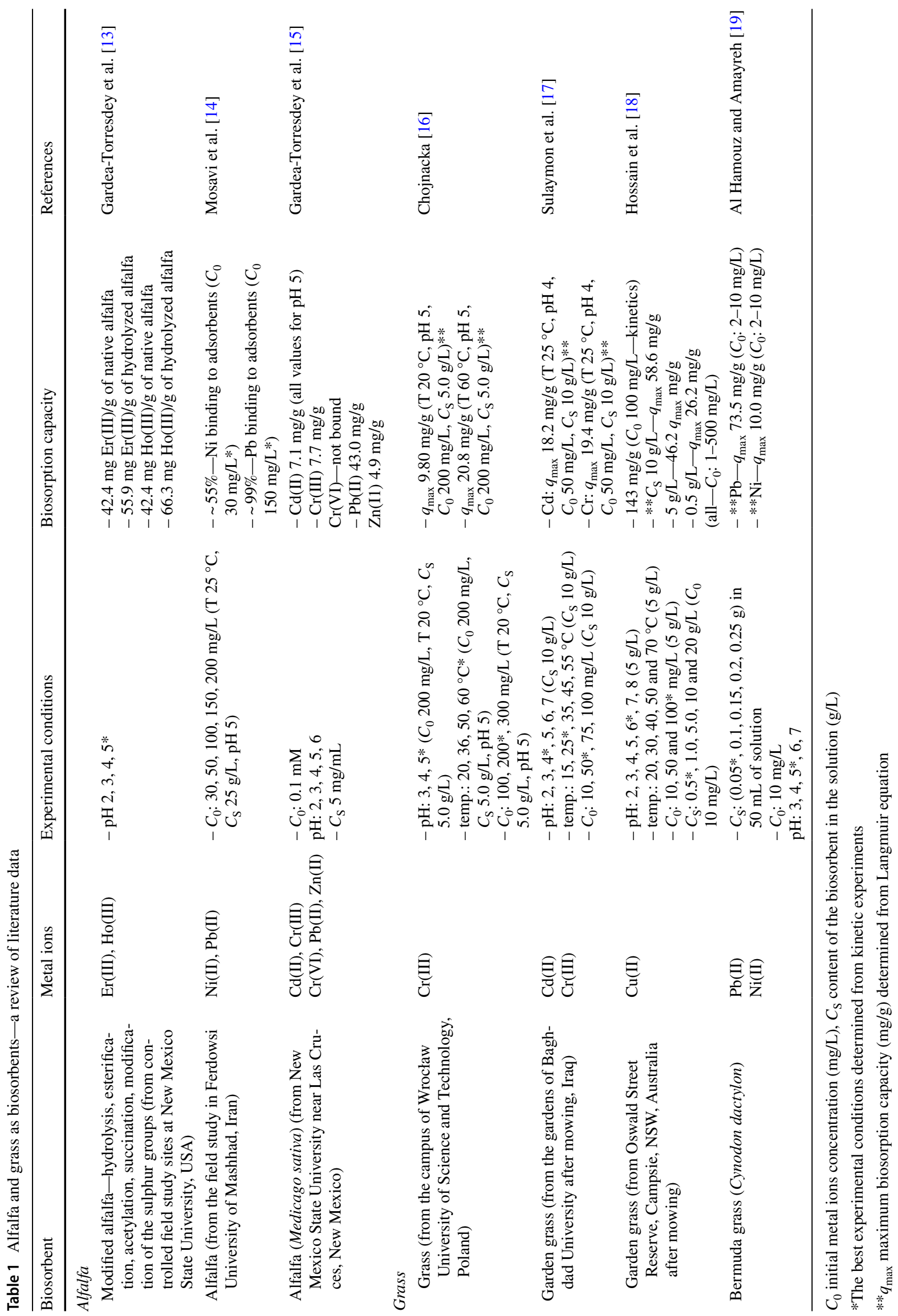


young chopped green oat (30\%), clover (10\%), sugar beet molasses $(5 \%)$ and vegetable oils $(5 \%)$.

2. chopped grass pellets (http://hippovetpl.shoper.pl/pl/p/ PreAlpin-Wiesencobs-25-kg/124) composed of unique mixture of over 60 different grasses and herbs of the Bavarian foothills of the Alps. The fields are under constant supervision and are harvested at the right time of maturation. This ensures low protein and a high fibre content for optimum horse nutrition.

3. chopped grass (http://hippovetpl.shoper.pl/pl/p/PreAl pin-Aspero-20-kg/125) — a very special chaff/chop produced from a blend of 60 grasses and herbs from the foothills of the Bavarian Alps, lightly sprayed with cold pressed linseed ( $2 \%$ added).

Before the use in the biosorption studies, the listed raw biomass (Fig. 1) was finely ground using RETSCH Knife Mill Grindomix GM300 (Germany).

Their chemical composition provided by the Producer (HippoVet+ (Poland)) is presented in Table 2.

\section{Biosorption Process}

In order to compare biosorption properties of each tested biomass, biosorption capacity $\left(q_{\mathrm{t}} ; \mathrm{mg} / \mathrm{g}\right)$ was calculated as the difference between the initial $\left(C_{0} ; \mathrm{mg} / \mathrm{L}\right)$ and final $\left(C_{\mathrm{t}}\right.$ at time $t ; \mathrm{mg} / \mathrm{L}$ ) concentration of metal ions in the solution divided by the concentration of this biomass in the solution $(\mathrm{g} / \mathrm{L})$. In other words, biosorption capacity is a mass of ions $(\mathrm{mg})$ bound by the mass of the sorbent $(\mathrm{g})$ [11].

\section{Kinetic Studies}

The aim of kinetic experiments was to establish the best experimental conditions of biosorption process $(\mathrm{pH}$ and the initial concentration of metal ions in the aqueous solution) and to establish time required to reach the process equilibrium. Additionally, pseudo-second order model (1) was used
Table 2 The chemical composition of the biomass used in the biosorption experiments

\begin{tabular}{llll}
\hline Nutritive value (in 1 kg) & Alfalfa & $\begin{array}{l}\text { Chopped } \\
\text { grass pellets }\end{array}$ & $\begin{array}{l}\text { Chopped } \\
\text { grass }\end{array}$ \\
\hline Crude protein (\%) & 12.0 & 8.6 & 9.1 \\
Crude fibre (\%) & 32.0 & 28.6 & 26.6 \\
Crude fat (\%) & 2.4 & 1.6 & 2.0 \\
Crude ash (\%) & 10.9 & 7.6 & 7.0 \\
Digestible energy (MJ/kg) & 10.5 & 8.9 & 9.8 \\
Digestible protein (g/kg) & 82.0 & 52.0 & 56.0 \\
Sugar (\%) & 10.0 & 3.1 & - \\
Starch (\%) & - & 2.2 & - \\
Fe (mg) & 615 & 721 & 583 \\
Zn (mg) & 22.0 & 33.0 & 41.0 \\
Mn (mg) & 33.0 & 114 & 86.0 \\
Cu (mg) & 9.0 & 8.4 & 12.0 \\
Se (mg) & 0.3 & 0.01 & 0.01 \\
Ca (\%) & 1.20 & 0.7 & 0.65 \\
P (\%) & 0.30 & 0.20 & 0.23 \\
Mg (\%) & 0.30 & 0.20 & 0.21 \\
Na (\%) & 0.10 & 0.05 & 0.02 \\
K (\%) & 2.1 & 1.3 & 1.5 \\
S (mg) & 2000 & 1347 & 1347 \\
Vit. E (mg) & 110 & 67.8 & 68.0 \\
Carotene (mg) & 112 & 63.3 & 54.8 \\
\hline The compor & & & \\
\hline
\end{tabular}

The composition was provided by the producer-HippoVet+ (Poland)

to determine biosorption capacity at equilibrium $\left(q_{\mathrm{eq}}, \mathrm{mg} / \mathrm{g}\right)$ and $k_{2}$ which is the rate constant of second-order biosorption (g/mg min).

$\frac{d q}{d t}=k_{2} \times\left(q_{e q}-q_{t}\right)^{2}$

Linear form of Eq. [1] is expressed as:

$\frac{t}{q_{t}}=\frac{1}{k_{2} \times q_{e q}^{2}}+\frac{t}{q_{e q}}$ (a) alfalfa

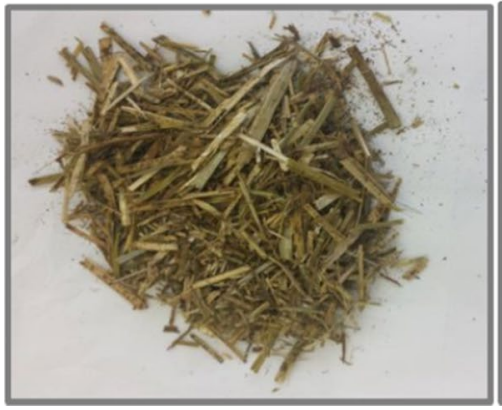

(b) chopped grass pellets

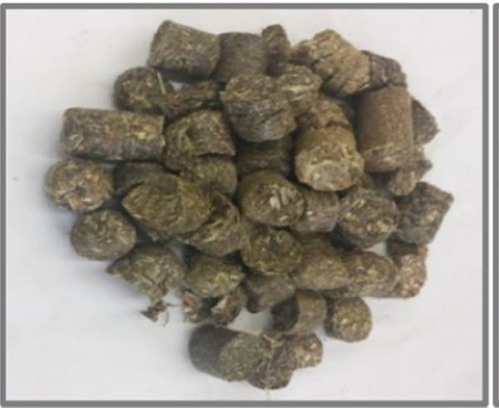

(c) chopped grass

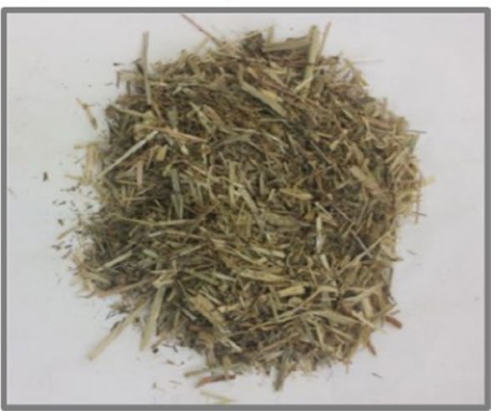

Fig. 1 Biomass used as a biosorbent of microelement ions 
where $q_{\mathrm{t}}$ is the amount of adsorbed metal ions on the biosorbent at time $t(\mathrm{mg} / \mathrm{g})$. The plot of $\mathrm{t} / q_{\mathrm{t}}$ against $t$ (Eq. 2) gives a linear relationship, from which $q_{\mathrm{eq}}$ and $k_{2}$ can be determined. This model is the most often used for the description of biosorption of metal ions by biosorbents [30, 31].

For this reason, $\mathrm{Cr}(\mathrm{III})$ ions (as an inorganic salt $\left.\mathrm{Cr}\left(\mathrm{NO}_{3}\right)_{3} \cdot 9 \mathrm{H}_{2} \mathrm{O}\right)$ were chosen due to simple method of their determination in aqueous solutions-spectrophotometric method [32]. Kinetics experiments for biosorption were performed in Erlenmeyer flasks containing $200 \mathrm{~mL}$ of $\mathrm{Cr}$ (III) solution at agitating rate-150 rpm (IKA KS 260 basic) and room temperature $\left(20^{\circ} \mathrm{C}\right)$ for $3 \mathrm{~h}$. The examined experimental conditions were as follows:

(1) Effect of initial $\mathrm{Cr}(\mathrm{III})$ concentration $\left(C_{0}\right)$ on the biosorption capacity was examined for $C_{0}: 100,200$ and $300 \mathrm{mg} / \mathrm{L}\left(\mathrm{pH} 5\right.$, biomass concentration $\left(C_{\mathrm{S}}\right)$ $1.0 \mathrm{~g} / \mathrm{L})$;

(2) Effect of $\mathrm{pH}$ on the biosorption capacity was examined for $\mathrm{pH}: 3,4$ and $5\left(C_{\mathrm{S}} 1.0 \mathrm{~g} / \mathrm{L}, C_{0} 300 \mathrm{mg} / \mathrm{L}\right)$.

$\mathrm{pH}$ of the solutions was adjusted with $0.1 \mathrm{~mol} / \mathrm{L}$ solution $\mathrm{NaOH} / \mathrm{HCl}$ using $\mathrm{pH}$ meter Mettler-Toledo (Seven Multi; Greifensee, Switzerland) equipped with an electrode InLab413 with compensation of temperature. Detailed description of kinetic experiments can be found in the work of Michalak and Chojnacka [31].

\section{Biosorption Equilibrium}

The equilibrium studies were performed in order to determine from the Langmuir model [33] the maximum possible amount of metal ions sorbed per gram of biosorbent $-q_{\max }$ $(\mathrm{mg} / \mathrm{g})$ and the affinity of binding sites for the metal ions$b(\mathrm{~L} / \mathrm{mg})$ which is a Langmuir adsorption constant. These parameters were determined after linearization of Eq. [3]:

$q_{e q}=\frac{q_{\max } b C_{e q}}{1+b C_{e q}}$

Linear form of Langmuir equation is expressed as:

$\frac{1}{q_{e q}}=\frac{1}{b \times q_{\max } \times C_{e q}}+\frac{1}{q_{\max }}$

where $C_{\text {eq }}$ is concentration of metal ions in the solution in equilibrium $(\mathrm{mg} / \mathrm{L})$.

The essential characteristics and the feasibility of the Langmuir isotherm can be also expressed in terms of a dimensionless constant separation factor $R_{\mathrm{L}}$, which is defined as:

$R_{\mathrm{L}}=1 /\left(1+\mathrm{b} \times C_{0}\right)$ where $C_{0}$ is the highest initial concentration of metal ions in the solution $(\mathrm{mg} / \mathrm{L})$ and $b$ the Langmuir adsorption constant (L/mg). The $R_{\mathrm{L}}$ value implies the adsorption to be unfavourable for $R_{\mathrm{L}}>1$, linear for $R_{\mathrm{L}}=1$, favourable for the range $0<R_{\mathrm{L}}<1$ or irreversible for $R_{\mathrm{L}}=0$ [34].

The equilibrium experiments were performed in Erlenmeyer flasks containing $20 \mathrm{~mL}$ of metal ions solution in a shaker at $150 \mathrm{rpm}$ (detailed description in Michalak and Chojnacka, [35]). These experiments were carried out at the best process conditions $\left(25^{\circ} \mathrm{C}, \mathrm{pH} 5, C_{\mathrm{S}} 1.0 \mathrm{~g} / \mathrm{L}\right)$ determined in the kinetic experiments. The initial concentrations of $\mathrm{Cr}(\mathrm{III}), \mathrm{Zn}(\mathrm{II}), \mathrm{Cu}(\mathrm{II})$ and $\mathrm{Mn}$ (II) ions in the solutions were as follows: 10, 25, 50, 75, 100, 150, 200, 250 and $300 \mathrm{mg} / \mathrm{L}$. pH each of them was 5 . For the preparation of metal ion solutions, the following inorganic salts were used: $\mathrm{ZnSO}_{4} \cdot 7 \mathrm{H}_{2} \mathrm{O}, \mathrm{CuSO}_{4} \cdot 5 \mathrm{H}_{2} \mathrm{O}, \mathrm{MnSO}_{4} \cdot \mathrm{H}_{2} \mathrm{O}$. The contact time was $2.5 \mathrm{~h}$ (determined from the kinetic experiments).

\section{Biosorption in a Fixed-Bed Column}

The aim of this experiment was to enrich the biomass with microelements in the column system to obtain feed additive for horses. This system is known to be more effective (amount of the enriched biomass production) than the batch system. The examined biomasses ( $20 \mathrm{~g}$ ) were stacked separately into glass columns with the volume of $0.5 \mathrm{~L}$. The microelements bearing solutions $\left(C_{0} 250 \mathrm{mg} / \mathrm{L}, \mathrm{pH} 5\right)$ were continuously pumped upward into the column. The flow rate was $1 \mathrm{~mL} / \mathrm{min}$. The process lasted for $4 \mathrm{~h}$. After the process, the enriched biomass was dried and subjected to the ICPOES and SEM-EDX analysis. It allowed to characterize the biomass (chemical composition), as well as to examine the mechanism of the biosorption process.

\section{Analytical Methods}

\section{Spectrophotometric Method}

The concentration of $\mathrm{Cr}$ (III) ions in the solution (4 mL) before and after biosorption process was determined spectrophotometrically $(\lambda 540 \mathrm{~nm})$ by complexation with EDTA (thylenediaminetetraacetic acid; $0.095 \mathrm{~g}$ ) using Varian Cary 50 Conc. Instrument (Victoria, Australia). EDTA reacts with $\mathrm{Cr}$ (III) and forms a stable, violet-coloured complex at higher temperatures $\sim 95^{\circ} \mathrm{C}$. Detailed description of the methodology can be found in the work of Michalak and Chojnacka [31] and $\mathrm{Ni}$ et al. [32]. 
Inductively Coupled Plasma-Optical Emission Spectrometry

The concentrations of $\mathrm{Cu}$ (II), $\mathrm{Mn}$ (II), $\mathrm{Zn}$ (II) in the solutions before and after biosorption process (equilibrium studies), as well as the content of micro- and macroalements in the biomass enriched in a fixed-bed column system were determined by ICP-OES technique (inductively coupled plasma optical emission spectrometry) using Varian VISTA-MPX ICP-OES spectrometer (Victoria, Australia) in the Chemical Laboratory of Multielemental Analysis at Wrocław University of Science and Technology accredited by International Laboratory Accreditation Cooperation Mutual Recognition Arrangement and Polish Centre for Accreditation. Before the analysis, enriched biomass (about $0.5 \mathrm{~g}$ ) was digested with $5 \mathrm{~mL}$ of concentrated $69 \%$ nitric acid (Supra pure grade from Merck, Darmstadt, Germany) in Teflon bombs in a microwave oven (type Milestone MLS-1200 MEGA, Bergamo, Italy). The solution after mineralization was diluted to $50 \mathrm{~mL}$ and analysed by ICP-OES [20, 31].

\section{Scanning Electron Microscopy with an Energy Dispersive X-ray Analytical System}

Scanning electron microscopy analysis combined with multielemental X-ray analysis of each biosorbent before and after biosorption was performed at Wrocław University of Environmental and Life Sciences. Samples of the examined biosorbents were dehydrated in alcohol series, dried, placed on an appropriate stub and gold-sputtered (using Scancoat 6 equipment-Oxford). All samples were analysed using a EVO Zeiss LS15 (Oberkochen, Germany), operating at $20 \mathrm{kV}$. The X-ray analysis were carried out with application of Rontec system (Bruker, Germany) according to previously described method [36-38].

\section{Results and Discussion}

In the present study we examined biosorption properties of three biomasses that are used in horse feeding. For this reason, alfalfa, chopped grass pellets and chopped grass were chosen. In the literature, this biomass is considered as a low-cost biosorbent used for the removal of toxic metals, for example alfalfa-biosorption of $\operatorname{Er}($ III) and Ho(III) [13], $\mathrm{Ni}(\mathrm{II})$ and $\mathrm{Pb}$ (II) [14]; $\mathrm{Cd}(\mathrm{II}), \mathrm{Cr}(\mathrm{III}), \mathrm{Cr}$ (VI), $\mathrm{Pb}$ (II), $\mathrm{Zn}$ (II) [15]. Grass as a biosorbent was used for the removal of $\mathrm{Cr}$ (III) [16, 17]; $\mathrm{Cd}$ (II) [17]; $\mathrm{Cu}$ (II) [18], $\mathrm{Pb}$ (II) and $\mathrm{Ni}$ (II) [19] (Table 1). Some of the listed metal ions, for example $\mathrm{Cr}(\mathrm{III}), \mathrm{Zn}(\mathrm{II}), \mathrm{Cu}(\mathrm{II})$ in small quantities are microelements that are required in horse feeding [1]. Therefore, the biomass of alfalfa and grass can be used to bind these metal ions via biosorption. Enriched biomass can then serve as a feed additive with microelements. Moreover, the chemical composition of the tested alfalfa and grass is suitable for horses with EMS, as it is recommended by their producer (Table 2). Therefore, the biomass enriched with mineral ions beside nutritional value can help in the management of EMS in horses.

\section{Kinetic Studies}

In this paper, the effect of $\mathrm{pH}$ and initial metal ions concentration on the parameters of pseudo-second order model were examined and the obtained data are presented in Table 3.

In the kinetic studies it was shown that the biosorption process was relatively fast-equilibrium was reached in around $80-100 \mathrm{~min}$. Based on our previous studies, we examined the effect of pH (Fig. 2) for $C_{0} 300 \mathrm{mg}$ of $\mathrm{Cr}(\mathrm{III})$ ions/L, room temperature and $C_{\mathrm{S}} 1 \mathrm{~g} / \mathrm{L}$. Previously it was found that for higher concentrations of metal ions $(>300 \mathrm{mg} / \mathrm{L}$ ) their amount bound with the biomass did not increase significantly. The difference in biosorption capacity of green macroalga-Enteromopha prolifera towards $\mathrm{Cr}$ (III) ions between 300 and $400 \mathrm{mg} / \mathrm{L}$ was small—only by $7 \%$ [31]. The aim of these experiments was to choose the optimal $C_{0}$ in order to obtain the biomass enriched in the highest extent with the metal ion (taking into consideration economical aspects related to the prices of inorganic salts used for the preparation of aqueous solutions with different concentrations of metal ions).

Metal biosorption is fully dependent on $\mathrm{pH}$ of water [17, $18,31,39]$ and it was also found in our study. At low $\mathrm{pH}$, the concentration of hydrogen ions $\left(\mathrm{H}^{+}\right)$increases and they compete with metal ions in the solution toward active sites on the surface of the biomass, leading to the lower biosorption capacity $[19,31]$.

The biosorption capacity of the biosorbents increased with $\mathrm{pH}$ - the highest $q_{\mathrm{eq}}$ was found for $\mathrm{pH} 5$. At $\mathrm{pH} 5$ the biosorption capacity for alfalfa and chopped grass pellets was about two times higher than in $\mathrm{pH} 4$ and about 3 times higher than in $\mathrm{pH}$ 3. For chopped grass $q_{\mathrm{eq}}$ at $\mathrm{pH} 5$ was about two times higher than at $\mathrm{pH} 4$ and 3 . When the initial $\mathrm{pH}$ of the solution was adjusted to a value higher than 5.5, chromium(III) ions precipitated as $\mathrm{Cr}(\mathrm{OH})_{3}$, because of higher concentration of $\mathrm{OH}^{-}$ions in the biosorption system [40].

Among three tested biosorbents, the highest $q_{\mathrm{eq}}$ at $\mathrm{pH}$ 5 was for alfalfa which was $22 \%$ higher than for chopped grass pellets and $55 \%$ higher than for chopped grass. The same tendency concerning the effect of $\mathrm{pH}$ on the sorption of $\mathrm{Cr}$ (III) ions by grass was observed by Chojnacka [16] $q_{\mathrm{eq}}$ increased with $\mathrm{pH}: \mathrm{pH} 3-q_{\mathrm{eq}} 7.15 \mathrm{mg} / \mathrm{g} ; \mathrm{pH} 4-q_{\mathrm{eq}}$ $7.31 \mathrm{mg} / \mathrm{g}$ and $\mathrm{pH} 5-q_{\mathrm{eq}} 14.1 \mathrm{mg} / \mathrm{g}\left(C_{0} 200 \mathrm{mg} / \mathrm{L}, 20{ }^{\circ} \mathrm{C}\right.$, $\left.C_{\mathrm{S}} 5.0 \mathrm{~g} / \mathrm{L}\right)$. In the work of Sulaymon et al. [17] it was found that the best $\mathrm{pH}$ value for $\mathrm{Cr}(\mathrm{III})$ removal by garden grass was around 4 and $q_{\mathrm{eq}}$ was about $20 \mathrm{mg} / \mathrm{g}$. Additionally, in the 
Table 3 Parameters of pseudo-second order model for biosorption kinetics ( $\mathrm{Cr}(\mathrm{III})$ ions)

\begin{tabular}{|c|c|c|c|c|}
\hline Biosorbent & Examined parameter & $q_{\mathrm{eq}}(\mathrm{mg} / \mathrm{g})$ & $k_{2}(\mathrm{~g} / \mathrm{mg} \min )$ & $R^{2}$ \\
\hline \multirow{3}{*}{$\begin{array}{l}\text { Alfalfa } \\
\left(C_{0} 300 \mathrm{mg} / \mathrm{L} ; C_{\mathrm{S}} 1 \mathrm{~g} / \mathrm{L}\right)\end{array}$} & pH 3 & 11.11 & 0.00764 & 0.9659 \\
\hline & $\mathrm{pH} 4$ & 15.15 & 0.0380 & 0.9466 \\
\hline & pH 5 & 36.36 & 0.0400 & 0.9634 \\
\hline \multirow{3}{*}{$\begin{array}{l}\text { Chopped grass pellets } \\
\left(C_{0} 300 \mathrm{mg} / \mathrm{L} ; C_{\mathrm{S}} 1 \mathrm{~g} / \mathrm{L}\right)\end{array}$} & $\mathrm{pH} 3$ & 11.82 & 0.00543 & 0.9701 \\
\hline & $\mathrm{pH} 4$ & 14.53 & 0.00788 & 0.7702 \\
\hline & pH 5 & 29.85 & 0.0240 & 0.9785 \\
\hline \multirow{3}{*}{$\begin{array}{l}\text { Chopped grass } \\
\left(C_{0} 300 \mathrm{mg} / \mathrm{L} ; C_{\mathrm{S}} 1 \mathrm{~g} / \mathrm{L}\right)\end{array}$} & pH 3 & 12.25 & 0.00594 & 0.7965 \\
\hline & $\mathrm{pH} 4$ & 12.64 & 0.0115 & 0.9291 \\
\hline & pH 5 & 23.42 & 0.0278 & 0.9194 \\
\hline \multirow{3}{*}{$\begin{array}{l}\text { Alfalfa } \\
\left(\mathrm{pH} 5 ; C_{\mathrm{S}} 1 \mathrm{~g} / \mathrm{L}\right)\end{array}$} & $C_{0} 100 \mathrm{mg} / \mathrm{L}$ & 27.55 & 0.00932 & 0.9868 \\
\hline & $C_{0} 200 \mathrm{mg} / \mathrm{L}$ & 38.02 & 0.00381 & 0.9903 \\
\hline & $C_{0} 300 \mathrm{mg} / \mathrm{L}$ & 36.36 & 0.0380 & 0.9659 \\
\hline \multirow{3}{*}{$\begin{array}{l}\text { Chopped grass pellets } \\
\left(\mathrm{pH} 5 ; C_{\mathrm{S}} 1 \mathrm{~g} / \mathrm{L}\right)\end{array}$} & $C_{0} 100 \mathrm{mg} / \mathrm{L}$ & 23.47 & 0.0218 & 0.9743 \\
\hline & $C_{0} 200 \mathrm{mg} / \mathrm{L}$ & 33.22 & 0.0915 & 0.9830 \\
\hline & $C_{0} 300 \mathrm{mg} / \mathrm{L}$ & 29.85 & 0.0240 & 0.9785 \\
\hline \multirow{3}{*}{$\begin{array}{l}\text { Chopped grass } \\
\left(\mathrm{pH} 5 ; C_{\mathrm{S}} 1 \mathrm{~g} / \mathrm{L}\right)\end{array}$} & $C_{0} 100 \mathrm{mg} / \mathrm{L}$ & 16.86 & 0.0414 & 0.9784 \\
\hline & $C_{0} 200 \mathrm{mg} / \mathrm{L}$ & 29.15 & 0.0668 & 0.9835 \\
\hline & $C_{0} 300 \mathrm{mg} / \mathrm{L}$ & 23.42 & 0.0278 & 0.9194 \\
\hline
\end{tabular}

present paper it was shown that the rate constant of secondorder model of biosorption, for all biosorbents, increased with $\mathrm{pH}$.

In the case of initial metal ions concentration (100, 200 and $300 \mathrm{mg} / \mathrm{L}$ ) the highest $q_{\text {eq }}$ for all biosorbents was determined for $C_{0} 200 \mathrm{mg} / \mathrm{L}$ (Fig. 3). This can indicate that at higher concentrations $\left(C_{0}>200 \mathrm{mg} / \mathrm{L}\right)$, the available sites for biosorption became fewer and the saturation of the sorption sites can be observed [17, 31]. In the case of alfalfa, $q_{\text {eq }}$ in $200 \mathrm{mg} / \mathrm{L}$ was $4.5 \%$ higher than in $300 \mathrm{mg} / \mathrm{L}$; for chopped grass pellets by $11 \%$ and for chopped grass by $24 \%$. These results are consistent with the data presented by Chojnacka [16], where $q_{\text {eq }}$ for $200 \mathrm{mg} / \mathrm{L}$ was $14.1 \mathrm{mg} / \mathrm{g}$ and for $300 \mathrm{mg} / \mathrm{L}$ was $14.3 \mathrm{mg} / \mathrm{g}\left(20^{\circ} \mathrm{C}, \mathrm{pH} 5.0, C_{\mathrm{S}} 5.0 \mathrm{~g} / \mathrm{L}\right)$. Among tested biosorbents, the best biosorption properties in these experimental conditions $\left(\mathrm{pH} 5, C_{0} 200 \mathrm{mg} / \mathrm{L}\right.$, room temperature, $\left.C_{\mathrm{S}} 1 \mathrm{~g} / \mathrm{L}\right)$ showed again alfalfa- $q_{\mathrm{eq}}$ was $14 \%$ higher than for chopped grass pellets and $30 \%$ higher than for chopped grass. The presented results showed that the value $k_{2}$ for the examined biosorbents did not depend on the initial concentration of $\mathrm{Cr}(\mathrm{III})$ ions.

\section{Biosorption Equilibrium}

The model parameters of Langmuir equation and dimensionless constant separation factor $R_{\mathrm{L}}$ are presented in Table 4.

The maximum biosorption capacity determined from Langmuir equation was similar for all biosorbents towards $\mathrm{Zn}$ (II) and Cr(III) ions. The mean $q_{\max }$ was $28.2 \pm 0.7 \mathrm{mg} / \mathrm{g}$ for $\mathrm{Zn}$ (II) ions and $31.6 \pm 2.2 \mathrm{mg} / \mathrm{g}$ for $\mathrm{Cr}$ (III) ions. In the case of $\mathrm{Cu}(\mathrm{II})$ and $\mathrm{Mn}(\mathrm{II})$ ions, mean $q_{\max }$ of alfalfa and chopped grass pellets was comparable and equal to $38.0 \pm 0.7$ for $\mathrm{Cu}$ (II) ions and $14.4 \pm 1.1 \mathrm{mg} / \mathrm{g}$ for $\mathrm{Mn}$ (II) ions. The maximum biosorption capacity of chopped grass towards $\mathrm{Cu}$ (II) ions was by $37 \%$ lower than mean $q_{\max }$ for alfalfa and chopped grass pellets. For Mn(II) ions, $q_{\text {max }}$ of chopped grass was more than two times higher than for alfalfa and chopped grass pellets. The order of $q_{\text {max }}$ determined from Langmuir equation was the same for alfalfa and chopped grass pellets: $\mathrm{Cu}>\mathrm{Cr}>\mathrm{Zn}>\mathrm{Mn}$. In the case of chopped grass, the order was as follows: $\mathrm{Cr}>\mathrm{Mn}>\mathrm{Zn}>\mathrm{Cu}$. Biosorption isotherms are shown in Fig. 4.

The values of $R_{\mathrm{L}}$ for biosorption of all tested metal ions by the examined biosorbents were in the range $0<R_{\mathrm{L}}<1$ what implies the adsorption to be favourable. Similar results were obtained by Sulaymon et al. [17] who examined the biosorption of $\mathrm{Cd}(\mathrm{II})$ and $\mathrm{Cr}(\mathrm{III})$ ions by garden grass. For both metal ions the values of $R_{\mathrm{L}}$ were in a range from 0 to 1 , indicating a favourable biosorption for both the metals.

The literature data concerning biosorption of microelement ions by alfalfa, chopped grass pellets and chopped grass are missing. Hossain et al. [18] examined biosorption of $\mathrm{Cu}$ (II) ions by garden grass at different initial concentrations (1-500 $\mathrm{mg} / \mathrm{L})$ of copper without adjusting $\mathrm{pH}$. The highest $q_{\max }$ was obtained for $C_{\mathrm{S}} 10 \mathrm{~g} / \mathrm{L}-58.6 \mathrm{mg} / \mathrm{g}$, then for $5 \mathrm{~g} / \mathrm{L}-46.2 \mathrm{mg} / \mathrm{g}$ and finally for $0.5 \mathrm{~g} / \mathrm{L}-26.2 \mathrm{mg} / \mathrm{g}$. However it is hard to compare these results, because as it was shown in the kinetic experiments, $\mathrm{pH}$ is the main factor that influences the biosorption capacity. 
(a) Alfalfa

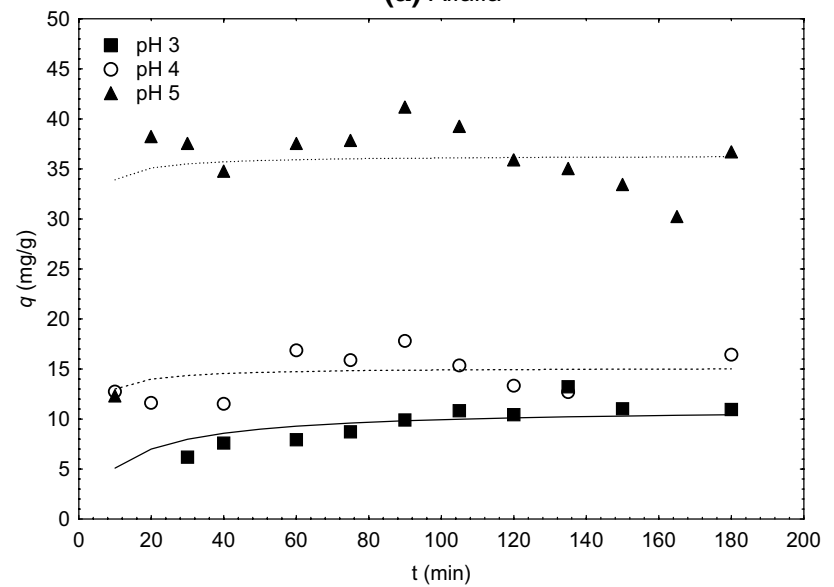

(b) Chopped grass pellets

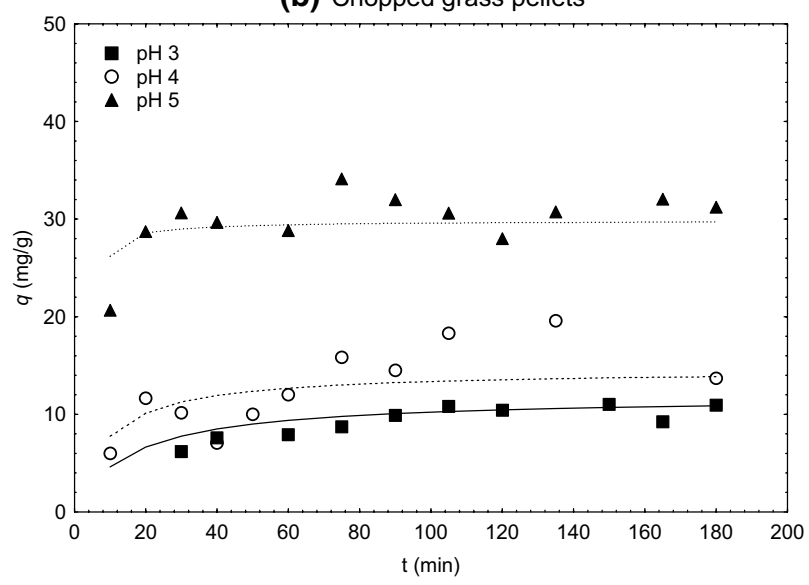

(c) Chopped grass

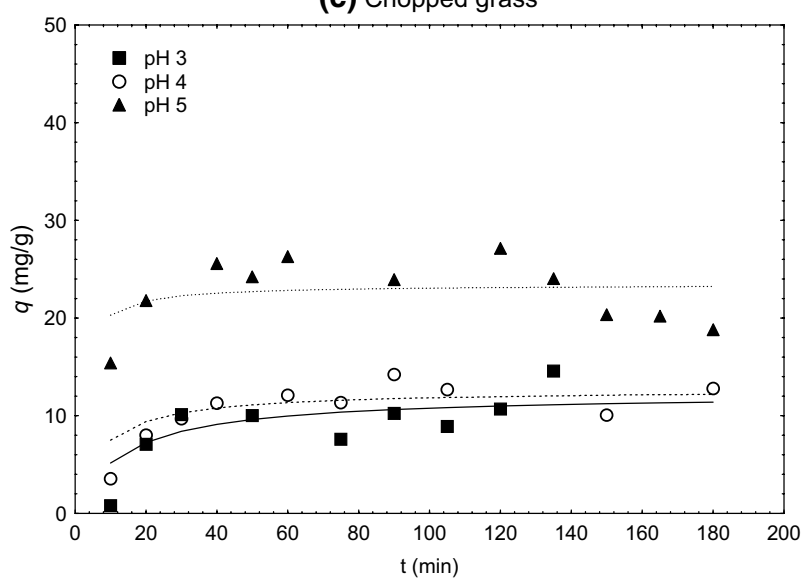

Fig. 2 Effect of $\mathrm{pH}$ on the biosorption of $\mathrm{Cr}(\mathrm{III})$ ions by biosorbents

\section{Biosorption in a Fixed-Bed Column}

The data obtained for biosorption under batch conditions are generally not applicable to most industrial processes, for example wastewater treatment, where column operations dominate. Biosorption in a batch system is used mainly to (a) Alfalfa

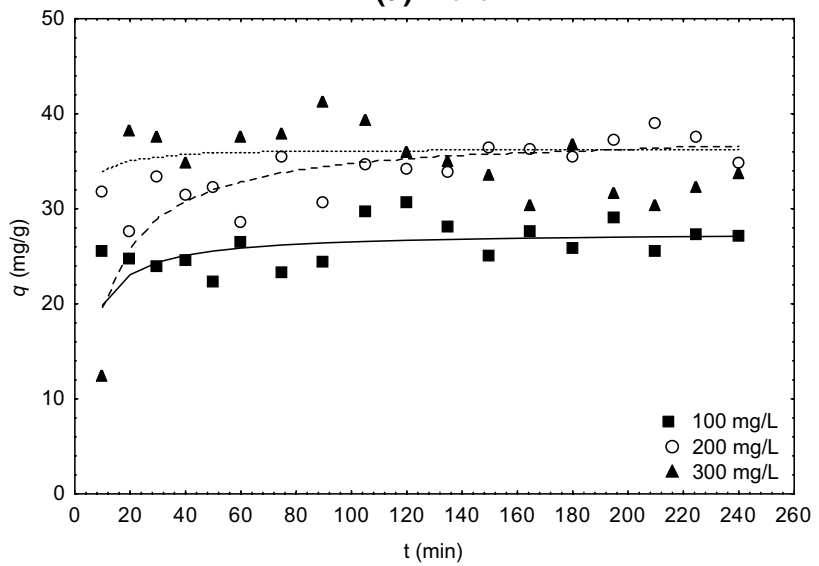

(b) Chopped grass pellets

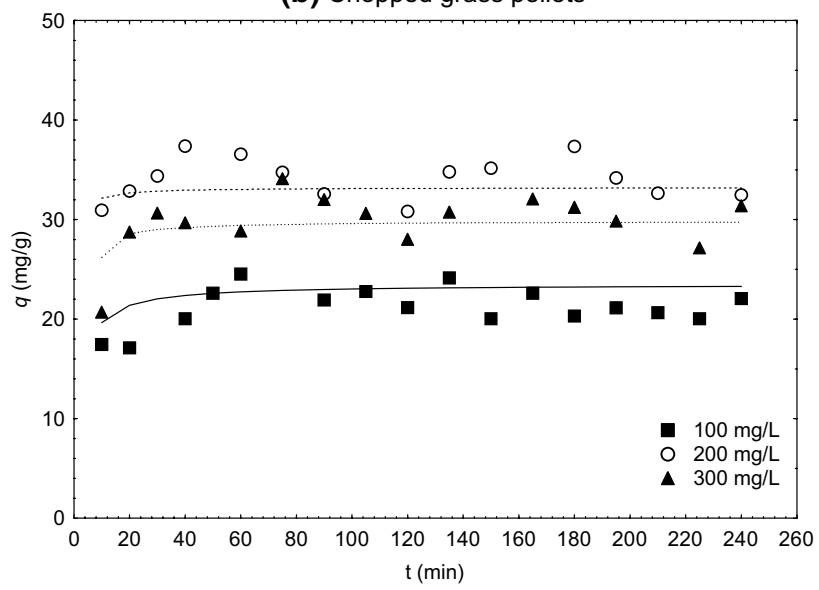

(c) Chopped grass

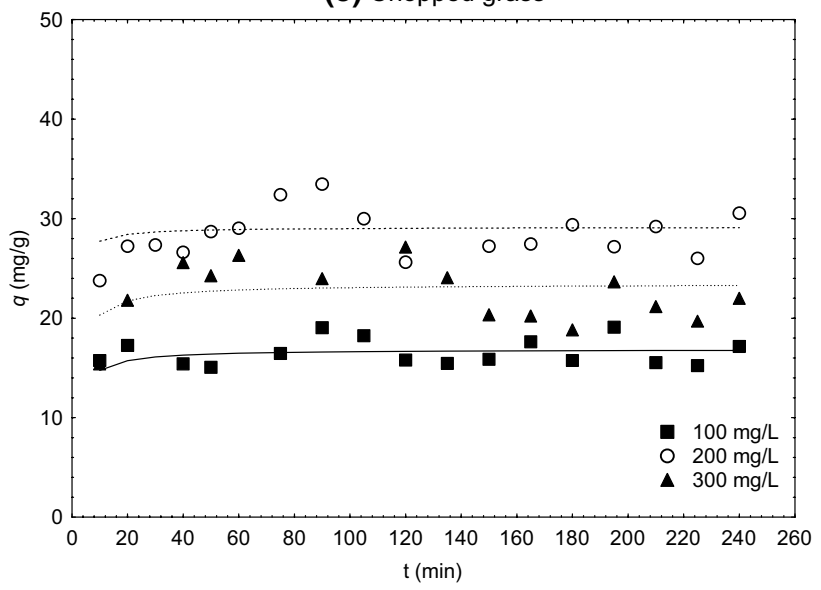

Fig. 3 Effect of the initial metal ions concentration on the biosorption of $\mathrm{Cr}(\mathrm{III})$ ions by biosorbents

determine the best experimental conditions for column operations [39]. For the production of new biosorptionbased preparations with microelements it is necessary to scale up the process from the laboratory to the larger scale (industrial). Samoraj et al. [41] proposed a new plant for 
Table 4 Parameters of Langmuir equation for examined biomasses $\left(25^{\circ} \mathrm{C}, \mathrm{pH} 5, C_{\mathrm{S}} 1.0 \mathrm{~g} / \mathrm{L}\right)$

\begin{tabular}{|c|c|c|c|}
\hline Parameters & Alfalfa & $\begin{array}{l}\text { Chopped grass } \\
\text { pellets }\end{array}$ & Chopped grass \\
\hline \multicolumn{4}{|l|}{$Z n(I I)$ ions } \\
\hline$q_{\max }(\mathrm{mg} / \mathrm{g})$ & 27.50 & 28.41 & 28.82 \\
\hline$b(\mathrm{~L} / \mathrm{mg})$ & 0.0470 & 0.0537 & 0.0715 \\
\hline$R^{2}$ & 0.9847 & 0.9600 & 0.9789 \\
\hline$R_{\mathrm{L}}$ & 0.0612 & 0.0539 & 0.0410 \\
\hline \multicolumn{4}{|l|}{$\mathrm{Cu}(\mathrm{II})$ ions } \\
\hline$q_{\max }(\mathrm{mg} / \mathrm{g})$ & 38.46 & 37.45 & 24.04 \\
\hline$b(\mathrm{~L} / \mathrm{mg})$ & 0.0176 & 0.0444 & 0.107 \\
\hline$R^{2}$ & 0.9675 & 0.9616 & 0.9532 \\
\hline$R_{\mathrm{L}}$ & 0.152 & 0.0662 & 0.0287 \\
\hline \multicolumn{4}{|l|}{$M n(I I)$ ions } \\
\hline$q_{\max }(\mathrm{mg} / \mathrm{g})$ & 13.62 & 15.22 & 33.47 \\
\hline$b(\mathrm{~L} / \mathrm{mg})$ & 0.1050 & 0.0998 & 0.0416 \\
\hline$R^{2}$ & 0.9827 & 0.8853 & 0.9578 \\
\hline$R_{\mathrm{L}}$ & 0.0305 & 0.0321 & 0.0863 \\
\hline \multicolumn{4}{|l|}{ Cr(III) ions } \\
\hline$q_{\max }(\mathrm{mg} / \mathrm{g})$ & 33.22 & 29.15 & 32.57 \\
\hline$b(\mathrm{~L} / \mathrm{mg})$ & 0.0172 & 0.0203 & 0.0254 \\
\hline$R^{2}$ & 0.9541 & 0.9311 & 0.9763 \\
\hline$R_{\mathrm{L}}$ & 0.179 & 0.157 & 0.130 \\
\hline
\end{tabular}

biosorption which is equipped with two independent reactors (70 L each) that can operate as a stirred tank or as a fixedbed column system. It was shown that the daily productivity was $300-400 \mathrm{~g}$ in the first option and $10-16 \mathrm{~kg}$ in the second one, which is more effective. The multielemental composition of the examined biomasses enriched with microelement ions in a fixed-bed columns in the laboratory scale is presented in Table 5.

This enrichment was performed in the best experimental conditions determined from kinetic studies. It was shown that the amount of metal ions bound by the biomass in a column system was as follows: for alfalfa- $2.6 \mathrm{mg} / \mathrm{g}$ for $\mathrm{Zn}, 2.0 \mathrm{mg} / \mathrm{g}$ for $\mathrm{Cu}, 1.6 \mathrm{mg} / \mathrm{g}$ for $\mathrm{Mn}$ and $2.1 \mathrm{mg} / \mathrm{g}$ for Cr. For chopped grass pellets these values were as follows: $3.0 \mathrm{mg} / \mathrm{g}$ for $\mathrm{Zn}, 3.4 \mathrm{mg} / \mathrm{g}$ for $\mathrm{Cu}, 2.2 \mathrm{mg} / \mathrm{g}$ for $\mathrm{Mn}$ and $2.1 \mathrm{mg} / \mathrm{g}$ for $\mathrm{Cr}$. In the case of chopped grass, we obtained: $2.7 \mathrm{mg} / \mathrm{g}$ for $\mathrm{Zn}, 3.5 \mathrm{mg} / \mathrm{g}$ for $\mathrm{Cu}, 1.8 \mathrm{mg} / \mathrm{g}$ for $\mathrm{Mn}$ and for $\mathrm{Cr}$. Results obtained in this study show that it was possible to significantly increase the content of a given microelement in the tested biomass. For example, in alfalfa the content of $\mathrm{Cr}$ in the enriched biomass increased 549 times when compared with natural biomass, content of $\mathrm{Cu} 321$ times, content of Mn 90 times and content of $\mathrm{Zn} 158$ times. Additionally from these results it can be seen that one of the mechanisms of biosorption process is ion exchange, in which alkali and alkaline earth metal ions (e.g., K, Ca, Mg) bound with functional groups (mainly carboxyl, hydroxyl) on the surface of the biomass are exchanged with metal ions from aqueous solution $[11,39]$. In the present study, the dominating metal ion that was exchanged was $\mathrm{K}$ and $\mathrm{Mg}$. Taking into account practical and economical point of view, biosorption in column is regarded as a more efficient method than in a batch system [15].

\section{SEM Micrographs of Natural and Enriched Biomass}

SEM-EDX technique gives the possibility to analyse the surface composition of the biomass before and after biosortion process. This method is used for the identification of elements visible only on the surface of biomass, as well as for observation of morphological changes in the biomass, e.g. shrinking after modifications [37]. The multielemental analysis of the examined biomass i.e. alfalfa, chopped grass pellet and chopped grass using SEM-EDX technique, as well as the SEM images are presented in Figs. 5, 6 and 7. It was shown, that the biosorption of $\mathrm{Cr}, \mathrm{Cu}, \mathrm{Mn}$ and $\mathrm{Zn}$ ion by alfalfa resulted in the final biomass enrichment with $\mathrm{Cr}$ equal to $0.71 \mathrm{wt} \%$ (weight percentage), 0.94, 1.16 and $0.97 \mathrm{wt} \%$ respectively. In turn, chopped grass pellet enriched with $\mathrm{Cr}$, $\mathrm{Cu}, \mathrm{Mn}$ and $\mathrm{Zn}$ ions resulted in the final biomass enrichment in $\mathrm{Cr}$ equal to $0.88,1.54,0.90$ and $0.86 \mathrm{wt} \%$ respectively. Chopped grass enriched with $\mathrm{Cr}, \mathrm{Cu}, \mathrm{Mn}$ and $\mathrm{Zn}$ ion exhibited following final biomass enrichment: $\mathrm{Cr} 1.02 \mathrm{wt} \%, \mathrm{Cu}-$ non detected, $\mathrm{Mn}-1.46 \mathrm{wt} \%$ and $\mathrm{Zn}-0.36 \mathrm{wt} \%$. Performed analysis clearly showed that biosorption process resulted in the biomass enrichment when compared to the control biomass-not enriched with particular elements.

Taking into account SEM-EDX analysis it was shown that the highest amounts of $\mathrm{Cr}$ and $\mathrm{Mn}$ was observed in case of chopped grass surface, $\mathrm{Cu}$ for chopped grass pellet and $\mathrm{Zn}$ for alfalfa. Both, SEM-EDX and ICP-OES techniques confirmed that biosorption is a surface phenomenon, in which alkali and alkaline earth metal ions (e.g., $\mathrm{Na}, \mathrm{K}, \mathrm{Ca}, \mathrm{Mg}$ ) were exchanged by metal ions from aqueous solution [37, 39].

\section{The Enriched Biomass in the Supplementation of Horses Diet}

Minerals are particularly important for the health of horses. They play a significant role in a wide range of biochemical systems that affect every metabolic function in the horse [3]. In the present paper, a special attention was paid to manganese, copper, zinc and chromium. The NRC requirements for horses for the examined minerals are as follows: Mn 40 mg/kg, Cu 10 mg/kg, Zn 40 mg/kg (content in total diet, dry mass) [1]. The National Research Council does not have a specific recommendation for chromium. According to the guidelines of Pagan et al. [4], the recommend dose of 
(a) Biosorption of $\mathrm{Zn}(\mathrm{II})$ ions

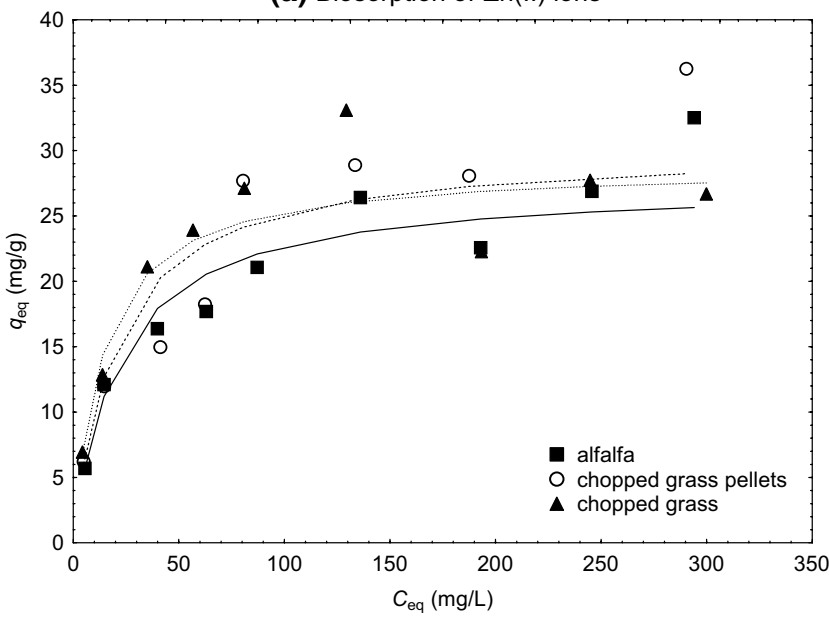

(b) Biosorption of $\mathrm{Cu}$ (II) ions

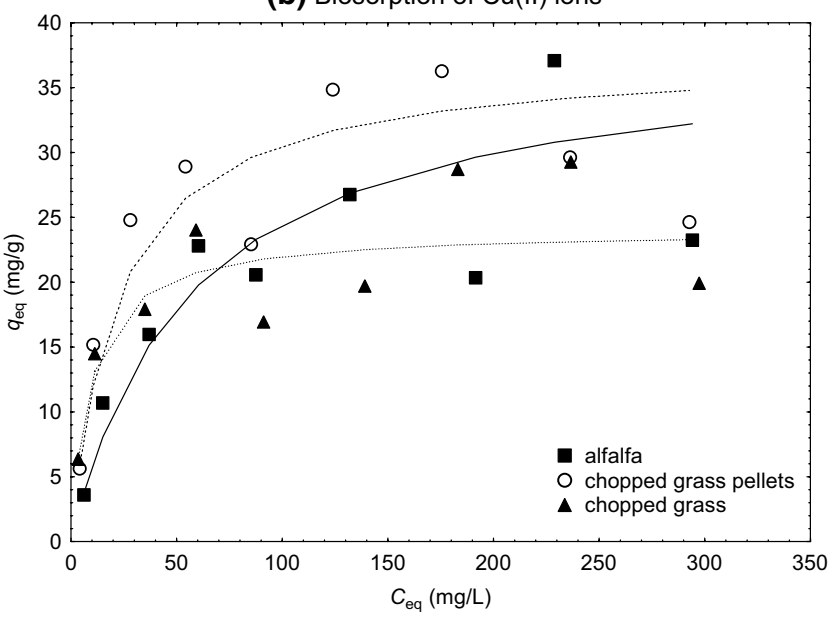

(c) Biosorption of $\mathrm{Mn}(\mathrm{II})$ ions

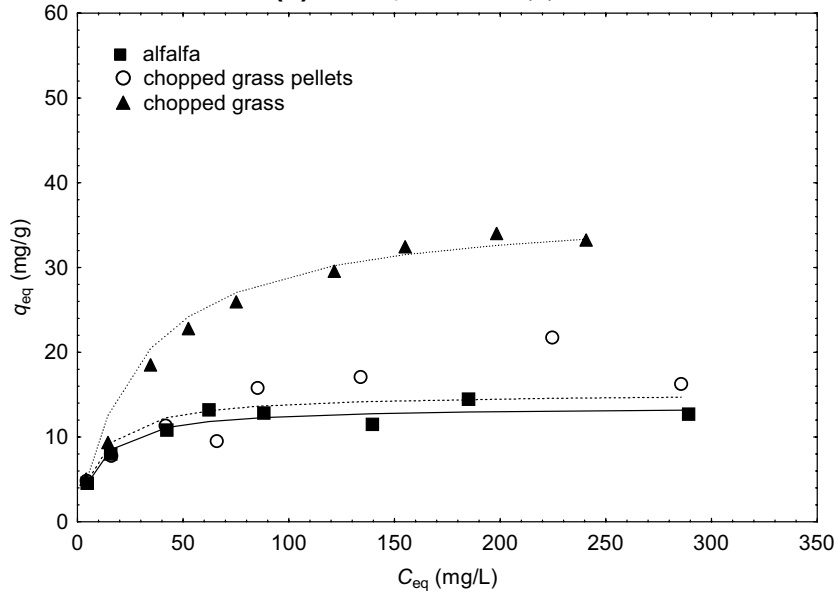

(d) Biosorption of $\mathrm{Cr}$ (III) ions

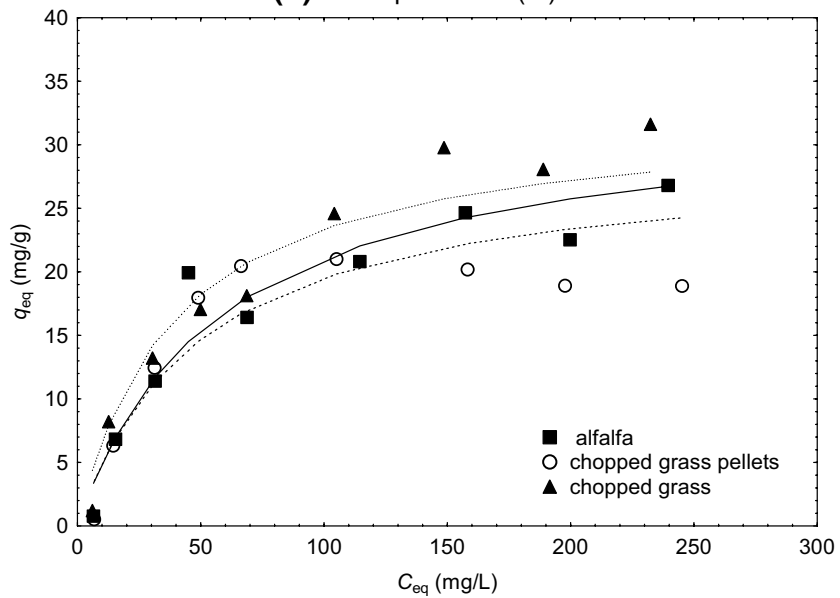

Fig. 4 Isotherms carried out for biosorption of a $\mathrm{Zn}(\mathrm{II})$ ions, $\mathbf{b} \mathrm{Cu}(\mathrm{II})$ ions, $\mathbf{c} \mathrm{Mn}$ (II) ions and $\mathbf{d} \mathrm{Cr}(\mathrm{III})$ ions by biosorbents at pH 5 and $C_{\mathrm{S}}$ $1.0 \mathrm{~g} / \mathrm{L}, 25^{\circ} \mathrm{C}$

chromium is $5 \mathrm{mg} /$ day. In order to cover this requirement for these minerals, the enriched biomass can be added to the feed instead of inorganic salts. This biomass would carry a biologically bound, concentrated form of microelements to the horse diet. Therefore the amounts added to the feed will be reduced, what is also beneficial taking into account the environmental aspect. For example, for alfalfa (taking into account the maximum biosorption capacity) the amount of the enriched biomass which should be added to $1 \mathrm{~kg}$ of feed will be: $1.5 \mathrm{~g}$ for $\mathrm{Zn}, 0.26 \mathrm{~g}$ for $\mathrm{Cu}, 2.9 \mathrm{~g}$ for $\mathrm{Mn}$ and $0.15 \mathrm{~g}$ for $\mathrm{Cr}$. The literature data concerning supplementation of chromium in horse diet are contradictory. Pagan et al. [4] showed that supplementation of chromium in the form of chromium yeasts to the trained horse diet influenced the levels of plasma cortisol, glucose and insulin which were lower than in the control group. Chameroy et al. [9] showed that the supplementation of horse diet (laminitic obese horses) with chromium yeast ( $5 \mathrm{mg} /$ day) did not alter morphometric measurements (bodyweight, body condition, girth circumference, and neck circumference), blood variables, resting insulin concentrations or insulin sensitivity.

\section{Conclusions}

In the present paper, biosorption process of microelement ions by feedstuff components was used to produce concentrated form of elements for horses. For this reason, alfalfa, chopped grass pellets and chopped grass were chosen, since they are commonly used in horse feeding. The biosorption properties of the biomass were examined in kinetic and equilibrium experiments. On this basis, the best experimental conditions $\left(\mathrm{pH} \mathrm{5,} C_{0} 200 \mathrm{mg} / \mathrm{L}\right)$ were chosen from biosorption kinetics, as well as the maximum biosorption capacity for each metal ion from Langmuir equation was determined. In the case of $\mathrm{Zn}$ (II) 


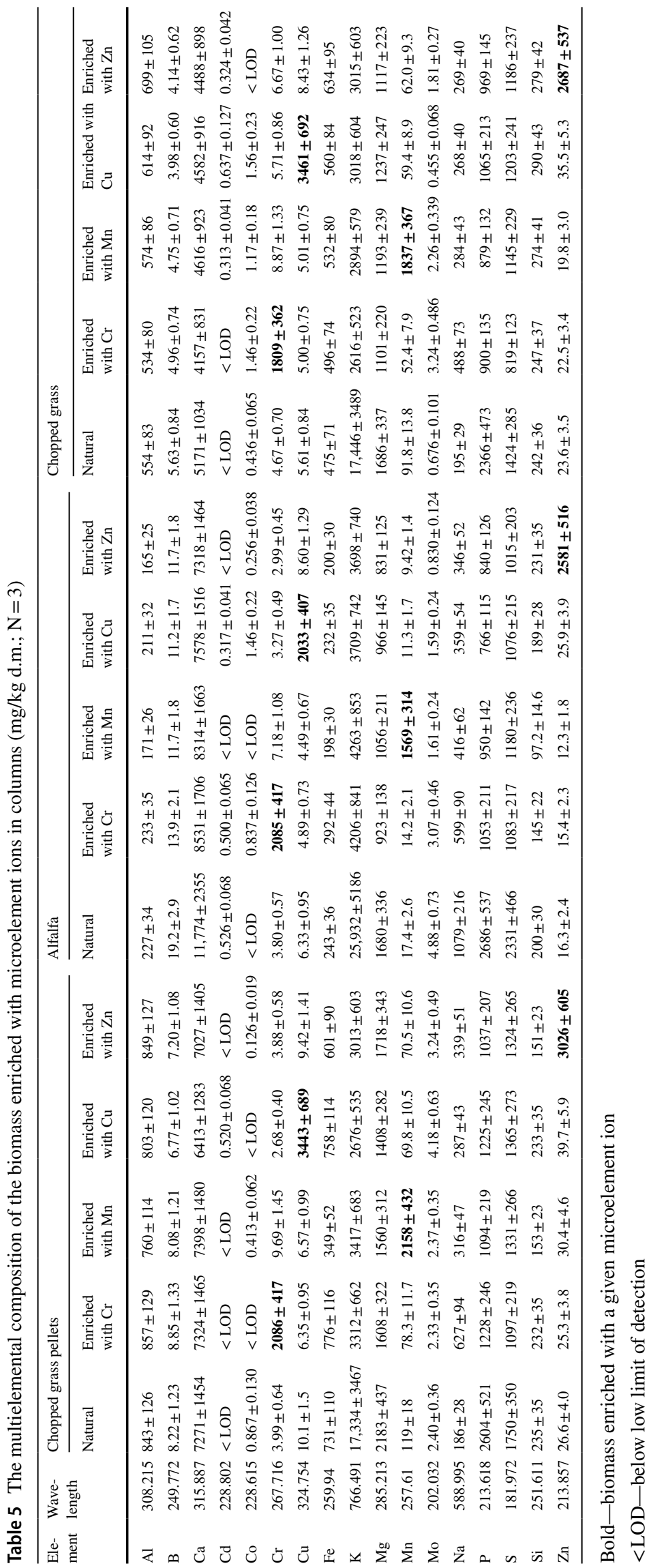



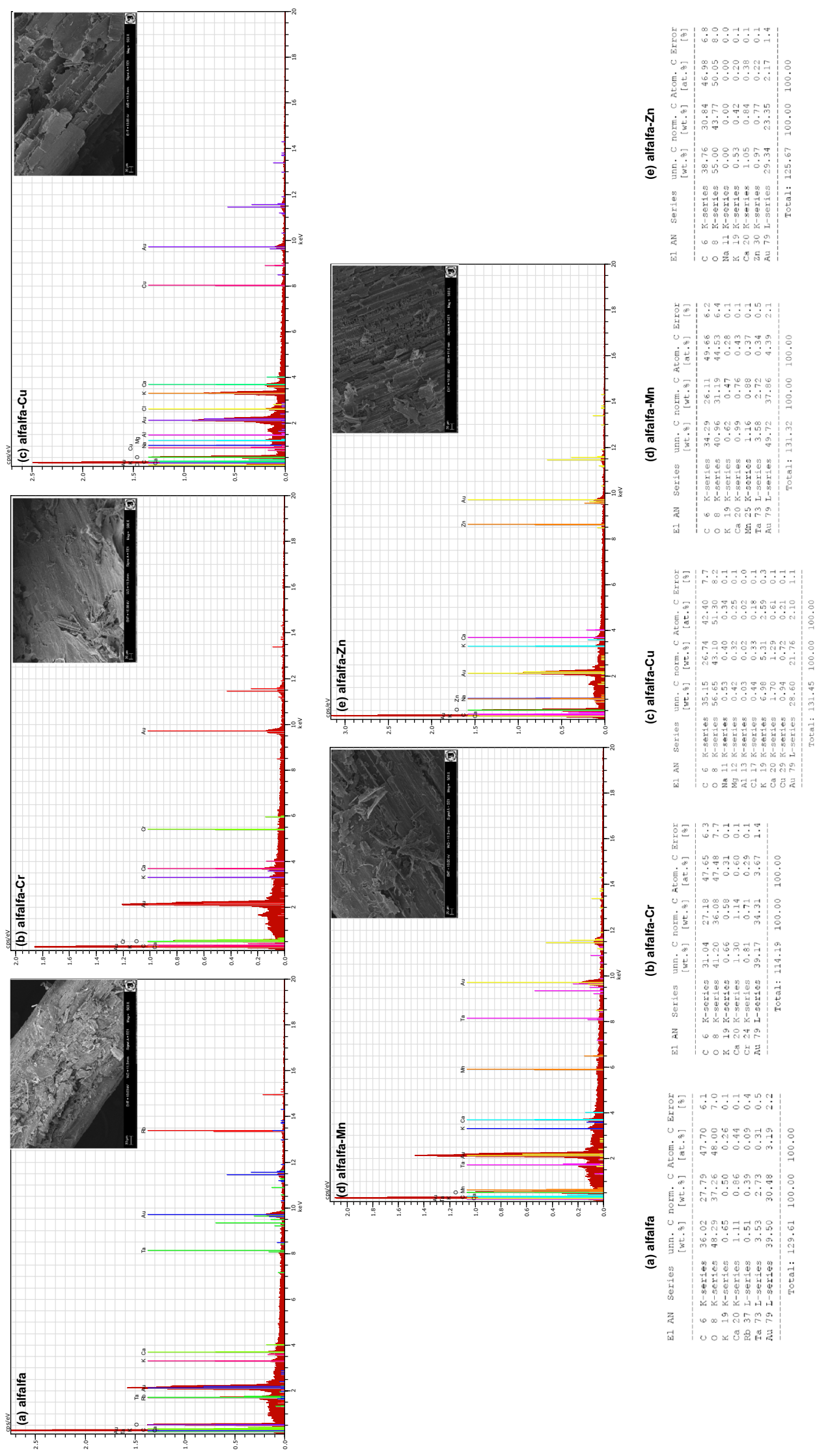

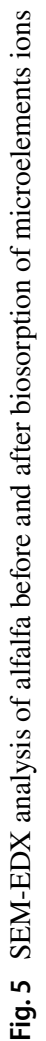



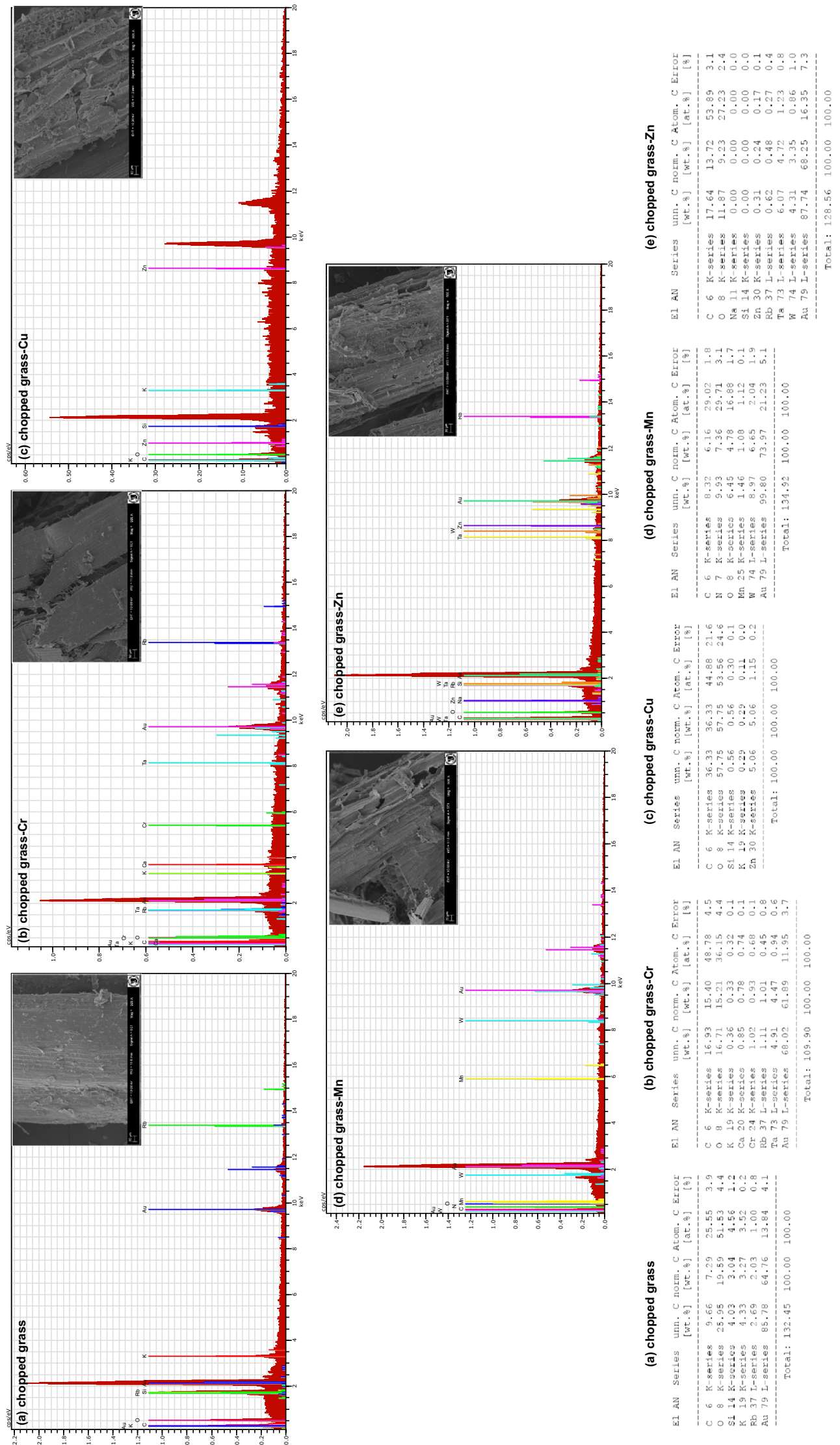

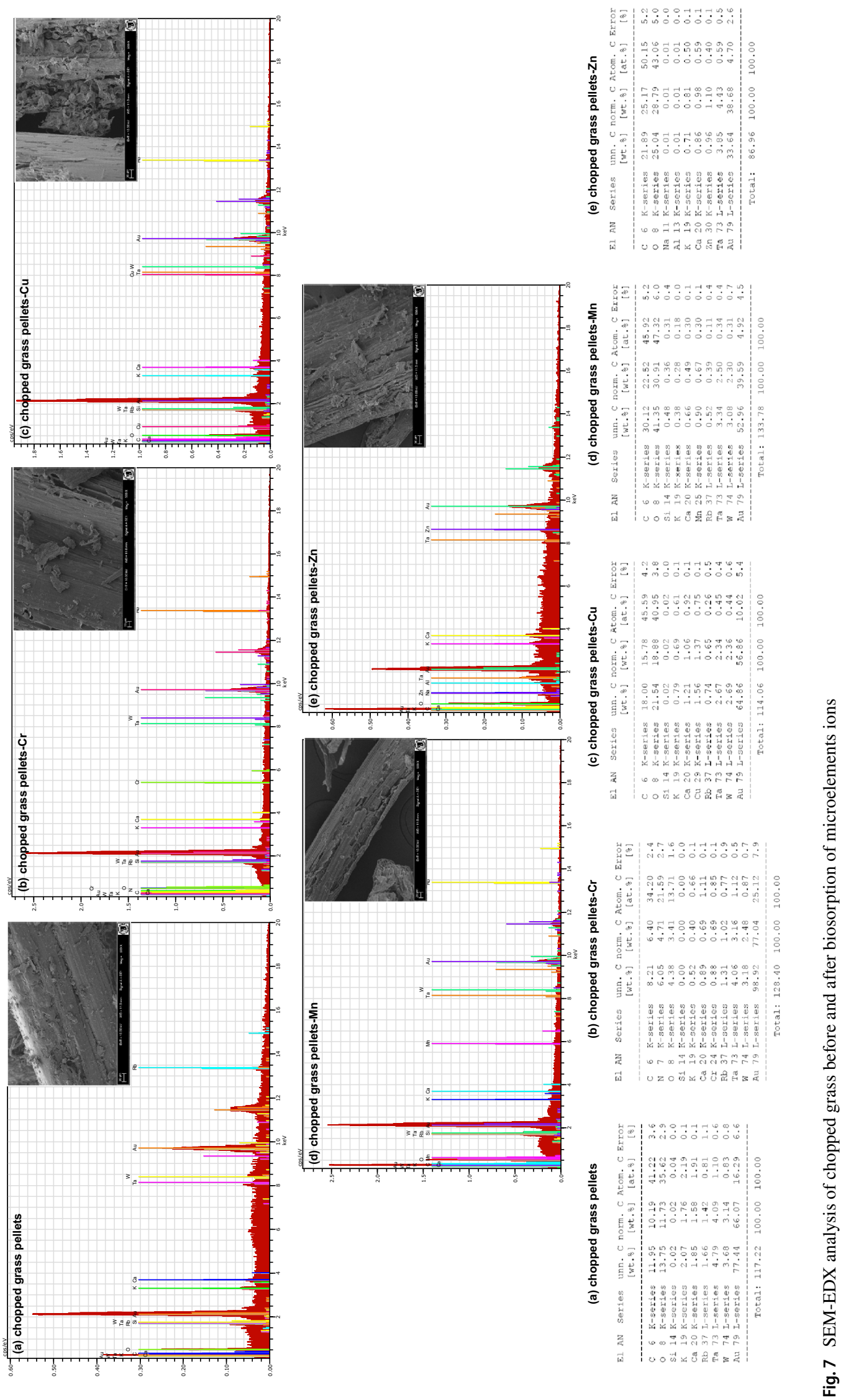
ions, the maximum biosorption capacity was comparable for all biosorbents-alfalfa, chopped grass pellets and chopped grass. For copper, the highest $q_{\max }$ was determined for alfalfa which was higher by $3 \%$ when compared with chopped grass pellets and by $37.5 \%$ higher than for chopped grass. Chopped grass was a good biosorbent of $\mathrm{Mn}$ (II) ions - $q_{\max }$ was more than two times higher than in the case of alfalfa and chopped grass pellets. The maximum biosorption capacity of alfalfa towards $\mathrm{Cr}$ (III) ions was the highest $-33.22 \mathrm{mg} / \mathrm{g}$, when compared with chopped grass pellets-29.15 mg/g and chopped grass$32.57 \mathrm{mg} / \mathrm{g}$. Concluding, among the tested biomasses, the best biosorption properties had alfalfa. In the next step, the biomass was enriched in a column system and then analysed using ICP-OES and SEM-EDX techniques. Both methods confirmed binding of metal ions by the biomassthe first one in the whole biomass, the second one on the surface of the samples. Taking into account the maximum biosorption capacity of the biosorbents, the amount of the enriched biomass which should be added to $1 \mathrm{~kg}$ of feed to cover the requirement of horses for a given element was calculated. For the best biosorbent-alfalfa these values are as follows: $1.5 \mathrm{~g}$ of the biomass enriched with $\mathrm{Zn}$, $0.26 \mathrm{~g}$ with $\mathrm{Cu}, 2.9 \mathrm{~g}$ with $\mathrm{Mn}$ and $0.15 \mathrm{~g}$ with $\mathrm{Cr}$. The enriched alfalfa can be recommended as a feed additive for horses. It will provide microelement ions in a highly bioavailable form, however it should be confirmed in the in vivo experiments.

Acknowledgements This project is financed in the framework of grant entitled-“"The effect of bioactive algae enriched by biosorption on the certain minerals such as $\mathrm{Cr}(\mathrm{III}), \mathrm{Mg}$ (II) and $\mathrm{Mn}$ (II) on the status of glucose in the course of metabolic syndrome horses. Evaluation in vitro and in vivo" (2015/18/E/NZ9/00607) attributed by The National Science Centre in Poland.

Open Access This article is distributed under the terms of the Creative Commons Attribution 4.0 International License (http://creativeco mmons.org/licenses/by/4.0/), which permits unrestricted use, distribution, and reproduction in any medium, provided you give appropriate credit to the original author(s) and the source, provide a link to the Creative Commons license, and indicate if changes were made.

\section{References}

1. NRC (2007) The Nutrient Requirements of Horses, 6th edn. National Academy Press, Washington DC.

2. Kania, M., Mikolajewska, D., Marycz, K., Kobielarz, M.: Effect of diet on mechanical properties of horse's hair. Acta Bioeng. Biomech. 11(3), 53-57 (2009)

3. Crandell, K.: (2003) Vitamin and mineral requirements in the horse. In: Zimmermann, N.G. (ed), Proceedings of the 50th Maryland Nutrition Conference for Feed Manufacturers and 1st Mid-Atlantic Nutrition Conference, March 27-28, 2003,
University of Maryland, Maryland Feed Industry Council, College Park, USA, pp. 195-202

4. Pagan, J.D., Jackson, S.G., Duren, S.E.: The effect of chromium supplementation on metabolic response to exercise in thoroughbred horses. In: Pagan, J.D. (ed.) Advances in Equine Nutrition, pp. 263-270. Nottingham University Press, Nottingham (1998)

5. Hummel, M., Standl, E., Schnell, O.: Chromium in metabolic and cardiovascular disease. Horm. Metab. Res. 39, 743-751 (2007). https://doi.org/10.1055/s-2007-985847

6. Vincent, J.B.: The biochemistry of chromium. J. Nutr. 130, 715718 (2000). https://doi.org/10.1093/jn/130.4.715

7. Jeejeebhoy, K.N.: Chromium and parenteral nutrition. J. Trace Elem. Exp. Med. 12, 85-89 (1999)

8. Kim, D.S., Kim, T.W., Park, I.K., Kang, J.S., Om, A.S.: Effects of chromium picolinate supplementation on insulin sensitivity, serum lipids, and body weight in dexamethasone-treated rats. Metabolism 51(5), 589-594 (2002). https://doi.org/10.1053/ meta.2002.31985

9. Chameroy, K.A., Frank, N., Elliott, S.B., Boston, R.C.: Effects of a supplement containing chromium and magnesium on morphometric measurements, resting glucose, insulin concentrations and insulin sensitivity in laminitic obese horses. Equine Vet. J. 43(4), 494-499 (2011). https://doi.org/10.1111/j.2042-3306.2010.00302 .x

10. Davis, T.A., Volesky, B., Mucci, A.: A review of the biochemistry of heavy metal biosorption by brown algae. Water Res. 37, 4311-4330 (2003). https://doi.org/10.1016/S0043-1354(03)00293 $-8$

11. Michalak, I., Chojnacka, K., Witek-Krowiak, A.: State of the art for the biosorption process-a review. Appl. Biochem. Biotechnol. 170, 1389-1416 (2013). https://doi.org/10.1007/s1201 0-013-0269-0

12. Michalak, I., Witek-Krowiak, A., Chojnacka, K., Bhatnagar, A.: Advances in biosorption of microelements-the starting point for the production of new agrochemicals. Rev. Inorg. Chem. 35(3), 115-133 (2015). https://doi.org/10.1515/revic-2015-0003

13. Gardea-Torresdey, J.L., Tiemann, K.J., Peralta-Videa, J.R., Parsons, J.G., Delgado, M.: Binding of erbium(III) and holmium(III) to native and chemically modified alfalfa biomass: a spectroscopic investigation. Microchem. J. 76, 65-76 (2004). https://doi. org/10.1016/j.microc.2003.10.012

14. Mosavi, S.B., Karimi, S., Feiziasl, V.: Biosorption of lead and nickel by Medicago sativa (alfalfa) and Datura from contaminated solution. Asian J. Chem. 22(3), 1700-1704 (2010)

15. Gardea-Torresdey, J.L., Gonzalez, J.H., Tiemann, K.J., Rodriguez, O., Gamez, G.: Phytofiltration of hazardous cadmium, chromium, lead and zinc ions by biomass of Medicago sativa (Alfalfa). J. Hazard Mater. 57(1-3), 290-293 (1998). https://doi.org/10.1016/ S0304-3894(97)00072-1

16. Chojnacka, K.: Biosorption of Cr(III) ions by wheat straw and grass: a systematic characterization of new biosorbents. Pol. J. Environ. Stud. 15(6), 845-852 (2006)

17. Sulaymon, A.H., Mohammed, A.A., Al-Musawi, T.J.: Comparative study of removal of cadmium (II) and chromium (III) ions from aqueous solution using low-cost biosorbent. Int. J. Chem. Reactor Eng. 12(1), 477-486 (2014). https://doi.org/10.1515/ijcre $-2014-0024$

18. Hossain, M.A., Ngo, H.H., Guo, W.S., Setiadi, T.: Adsorption and desorption of copper(II) ions onto garden grass. Bioresour. Technol. 121, 386-395 (2012). https://doi.org/10.1016/j.biort ech.2012.06.119

19. Al Hamouz, O.C.S., Amayreh, M.Y.: Removal of lead(II) and nickel(II) ions from aqueous solution via Bermuda grass biomass. J. Water Supply: Res. Technol.-AQUA. 65(6), 494-503 (2016). https://doi.org/10.2166/aqua.2016.013 
20. Michalak, I., Chojnacka, K., Dobrzański, Z., Górecki, H., Zielińska, A., Korczyński, M., Opaliński, S.: Effect of enriched with microelements macroalgae on egg quality parameters and mineral content of eggs, eggshell, blood, feathers and droppings. J. Anim. Physiol. Anim. Nutr. 95, 374-387 (2011). https://doi.org /10.1111/j.1439-0396.2010.01065

21. Michalak, I., Chojnacka, K., Korniewicz, D.: New feed supplement from macroalgae as the dietary source of microelements for pigs. Open Chem. 13, 1341-1352 (2015). https://doi.org/10.1515/ chem-2015-0149

22. Witkowska, Z., Michalak, I., Korczyński, M., Szołtysik, M., Świniarska, M., Dobrzański, Z., Tuhy, Ł, Samoraj, M., Chojnacka, K.: Biofortification of milk and cheese with microelements by dietary feed bio-preparations. J. Food Sci. Technol. 52(10), 64846492 (2015). https://doi.org/10.1007/s13197-014-1696-9

23. Basinska, K., Marycz, K., Śmieszek, A., Nicpoń, J.: The production and distribution of IL- 6 and TNF- $\alpha$ in subcutaneous adipose tissue and their correlation with serum concentrations in Welsh ponies with equine metabolic syndrome. J. Vet. Sci. 16(1), 113120 (2015). https://doi.org/10.4142/jvs.2015.16.1.113

24. Chameroy, K.A.: (2010) Diagnosis and management of horses with Equine Metabolic Syndrome (EMS). PhD Dissertation, University of Tennessee, Knoxville, USA. http://trace.tennessee.edu/ utk_graddiss/871. Accessed 28 Sept 2016

25. Frank, N., Geor, R.J., Bailey, S.R., Durham, A.E., Johnson, P.J.: Equine metabolic syndrome. J. Vet. Intern. Med. 24, 467-475 (2010). https://doi.org/10.1111/j.1939-1676.2010.0503.x

26. Marycz, K., Moll, E., Grzesiak, J.: Influence of functional nutrients on insulin resistance in horses with equine metabolic syndrome. Pak. Vet. J. 34(2), 189-192 (2014)

27. McGowan, C.M., Dugdale, A.H., Pinchbeck, G.L., Argo, C.M.G.: Dietary restriction in combination with a nutraceutical supplement for the management of equine metabolic syndrome in horses. Veter. J. 196, 153-159 (2013). https://doi.org/10.1016/j. tvj1.2012.10.007

28. Longland, A.C., Byrd, B.M.: Pasture nonstructural carbohydrates and equine laminitis. J. Nutr. 136, 2099S-2102S (2006)

29. Argo, C.M.G., Dugdale, A.H.A., McGowan, C.M.: Considerations for the use of restricted, soaked grass hay diets to promote weight loss in the management of equine metabolic syndrome and obesity. Veter. J. 206(2), 170-177 (2015). https://doi.org/10.1016/j. tvj1.2015.07.027

30. Aksu, Z.: Equilibrium and kinetic modelling of $\mathrm{Cd}(\mathrm{II})$ biosorption by $C$. vulgaris in batch system: effect of temperature. Sep. Purif. Technol. 21, 285-294 (2001)
31. Michalak, I., Chojnacka, K.: The new application of biosorption properties of Enteromorpha prolifera. Appl. Biochem. Biotechnol. 160, 1540-1556 (2010). https://doi.org/10.1007/s 1201 0-009-8635-7

32. Ni, Y., Chen, S., Kokot, S.: Spectrophotometric determination of metal ions in electroplating solutions in the presence of EDTA with the aid of multivariate calibration and artificial neural networks. Anal. Chim. Acta 463, 305-316 (2002). https://doi. org/10.1016/S0003-2670(02)00437-3

33. Langmuir, I.: The adsorption of gases on plane surfaces of glass, mica and platinum. J. Am. Chem. Soc. 40, 1361-1403 (1918)

34. McKay, G., Blair, H.S., Gardner, J.R.: The adsorption of dyes onto chitin in fixed bed columns and batch adsorbers. J. Appl. Pol. Sci. 29, 1499-1514 (1984)

35. Michalak, I., Chojnacka, K.: Edible macroalga Ulva prolifera as microelemental feed supplement for livestock: the fundamental assumptions of the production method. World J. Microbiol. Biotechnol. 25, 997-1005 (2009). https://doi.org/10.1007/s1127 4-009-9976-7

36. Kaliński, K., Marycz, K., Czogała, J., Serwa, E., Janeczek, W.: An application of scanning electron microscopy combined with roentgen microanalysis (SEM-EDS) in canine urolithiasis. J. Electron. Microsc. (Tokyo) 61(1), 47-55 (2012)

37. Michalak, I., Chojnacka, K., Marycz, K.: Using ICP-OES and SEM-EDX in biosorption studies. Mikrochim. Acta 172(1-2), 65-74 (2011). https://doi.org/10.1007/s00604-010-0468-0

38. Witek-Krowiak, A., Podstawczyk, D., Chojnacka, K., Dawiec, A., Marycz, K.: Modelling and optimization of chromium III biosorption on soybean meal. Cent. Eur. J. Chem. 11(9), 1505-1517 (2013). https://doi.org/10.2478/s11532-013-0274-8

39. Yahaya, Y.A., Don, M.M.: Pycnoporus sanguineus as potential biosorbent for heavy metal removal from aqueous solution: a review. J. Phys. Sci. 25(1), 1-32 (2014)

40. Yun, Y.S., Park, D., Park, J.M., Volesky, B.: Biosorption of trivalent chromium on the brown seaweed biomass. Environ. Sci. Technol. 35, 4353-4358 (2001). https://doi.org/10.1021/es010 $866 \mathrm{k}$

41. Samoraj, M., Tuhy, $Ł$, Chojnacka, K.: New bench scale plant for biosorption. Proceedings of TINOS 2015 3rd International Conference on Sustainable Solid Waste Management. TINOS Island, Greece, 24.07.2015 (2018). http://uest.ntua.gr/tinos2015/proce edings/pdfs/Samoraj.pdf. Accessed 10 Apr 2018 